\title{
A Theoretical Focus on Cultural Taxation: Who Pays for It in Higher Education
}

\author{
Dr. Roger Cleveland \\ Eastern Kentucky University \\ Dr. JaDora Sailes \\ Indiana State University \\ Dr. Erin Gilliam \\ Kentucky State University
}

\begin{abstract}
Jillian Watts
Director CARE Initiative, Green Dot Trained Instructor, Manchester University
\end{abstract}

\begin{abstract}
The representation of faculty of color at universities and colleges in the United States has increased. Yet, white professors still account for $84 \%$ of full-time faculty. Researchers suggest that along with institutionalized racism the mantra of publish or perish promotes racial disparities in academia. The scholarly demand of publishing is encumbered by all tenure track faculty. However, non-white faculty faces additional challenges as they pursue promotion and tenure. "Cultural taxation" is one of the most major occupational threats for faculty of color. This theoretical paper examines how "cultural taxation" may serve as an obstacle to success for faculty of color in the academy due to implicit and explicit discriminatory practices.
\end{abstract}

Keywords: leadership, academia, minority faculty, culture

\section{INTRODUCTION}

The representation of faculty of color at universities and colleges in the United States has increased. Yet, white professors still account for 84\% of full-time faculty (NCES, 2013). This disparity may be attributed to the demise of Affirmative Action. However, this belief would be shortsighted considering that there are other factors which contribute to the low presence of racial minority faculty in academia. An uninviting campus climate for non-white faculty plays a significant role in this disparity. Further, researchers suggest that along with institutionalized racism the mantra of publish or perish promotes racial disparities in academia. (Thomas and Hollenshead, 2001; Turner, 2003). The scholarly demand of publishing is encumbered by all tenure track faculty. However, non-white faculty faces additional challenges as they pursue promotion and tenure. "Cultural taxation" is one of the most major occupational threats for faculty of color (Conway-Jones, 2006).

Cultural taxation is best defined as the manner in which responsibilities are placed on racial minorities because of their minority status (Padilla, 1994). Cultural taxation is discriminatory and a form of racism because the tax is imposed as a result of a person's minority status or membership in a marginalized group. Marginalization can be defined as ongoing inequality and adversity resulting from stereotypes, discrimination and social stigma (National Democratic Institute, 2015). Marginalized groups have long been discriminated against and are often excluded from, but not limited to, politics, social groups/clubs/organizations and leadership 
positions. This exclusion is based on variables such as religion, disability, ethnicity, sexual orientation, age and/or gender. Cultural taxation was initially coined to describe what was happening to minorities in academic institutions across the country (Padilla, 1994). This taxation includes additional professional responsibilities, albeit not listed in the job description nor remunerated in the salary offer but nonetheless still expected by faculty of color. In short, while most tenure track instructional faculty members have many of the same responsibilities: "teaching, research, and service to the university and to the community" (Workload, Article 20, Section 20.1), non-white faculty have an increased workload based on their cultural membership.

\section{WHAT DOES IT LOOK LIKE?}

Cultural taxation is designed to appear as a service and a responsibility to the venue where one is employed. In The Politics of Survival in Academia: Narratives of Inequity, Resilience and Success, Jacobs, Cintron and Canton (2002) describe the manifestation of these additional duties and how they are based on variables such as race, gender and identity that are not articulated. Examples include the expectation of leadership whereby minority faculty members are knowledgeable and able to speak for a specific cultural group, and serve as the sole racial minority member on many committees. Oftentimes, they are strongly encouraged to conduct research pertinent to "exotic communities" (Canton, 2012). Being asked to translate documents (non-English) and provide clarity on diversity issues to the racial majority are other examples of cultural taxation. The institution may benefit from this form of expertise but non-white faculty are typically not rewarded by the institution (Padilla, 1994). Canton (2012), reported that minority faculty members may also be required to serve as advisors, mentors, therapists, and counselors to minority students. Minority students have different issues and concerns; especially at predominately white institutions where extra help is often needed in navigating through the complex social and political constructs of these institutions (Stanley, 2006) which further taxes the time of minority faculty. These added stressors of cultural taxation can take a toll on minority faculty who are expected to teach the same load and conduct the same amount of research as their white counterparts (Turner, 2003; ConwayJones, 2006). Research literature suggests that the increased obligations required from nonwhite faculty leads to higher levels of occupational stress (Conway-Jones, 2006; Stanley, 2006; Segura, 2003) which potentially results in more exposure to health related issues (Geronimus, 2006).

\section{CULTURAL TAXATION AND PROFESSIONAL SOCIAL CLIMATE}

Collegiality is essential on the pathway that leads to promotion and tenure. Faculty of color are often submitted to work environments that are less than favorable. The lack of camaraderie with white colleagues may contribute to isolation within departments and the institution (Essien, 2003). According to Ruffins (1997), faculty of color, especially females, must navigate "psychological minefields" because of the need to balance a high-stress academic life with a personal life that may include family obligations. Further these "double minorities" (women of color) are faced with additional issues as she is expected to be a role model for women and serve as expert for the minority group she represents (Smith, 2010). Black females have also noted being subjected by their colleagues' preoccupation with their clothing choices, hairstyle, and being admonished to play down their "passion" and "smile more" (McGee and Kazembe, 2015).

The absence of emotional and physical threat is key to successful work production.

Faculty of color have reported work environments which harbor micro-aggressions, subtle and stunning racial slights, to outright racism which often causes them mental anguish (McGee, 2015). This anguish is also evident in other professional arenas. In a study by McGee and 
Kazembe (2015), their research gave light to the term "presenting while Black". Black professors were interviewed about their participation in a number of presentation contexts, including national conferences, symposia and campus job talks. Majority of the Black faculty in the study reported they were advised regularly by white peers to be "more entertaining" when making research presentations, as well as to "lighten up," and "tell more jokes." Further, Black presenters' reported their research was met with shock and awe with comments like, "I had no idea you were that bright" and "I'm pleasantly surprised," (McGee and Kazembe, 2015). Both comments suggest low expectations had been established prior to the presentation. Faced with racial battle fatigue a byproduct of cultural taxation explains how the social environment (e.g., institutions, policies, practices, traditions, groups and individuals) perpetuates racerelated stressors that adversely affect professional productivity and retention (Smith, 2016) and eventually lead faculty of color to change who they are in order to fit in, or simply give up and change careers. (McGee and Kazembe, 2015).

\section{FINAL THOUGHTS}

There are many obstacles to success for faculty of color in the academy due to implicit and explicit discriminatory practices. Historically, higher education aimed to provide a framework where all tenure track faculty were granted the opportunity to meet necessary requirements for promotion and tenure. This ideal has not adopted universally in institutions of higher education. Given this reality, leadership needs to reconsider the implementation of a more accurate and fair assessment of determining promotion and tenure. Leadership should also realign and implement structural changes within departmental and university levels in order to balance the distribution of duties and create a more equitable environment (Joseph and Hirshfield, 2010). Cultural taxation will not cease to exist without a genuine and realistic dissection of institutional racism in our educational systems and in American society (Essien, 2003). Once society is ready to address the historical implications and atrocities of racism and discrimination, then we can truly address the issues that plague marginalized faculty.

\section{References}

Canton, C. (2012, Fall). The "cultural taxation" of faculty of color in the academy.

Conway-Jones, D. (2006). Being all things to all people: Expectations of and demands on women of color in the legal academy, in From oppression to grace: Women of color and their dilemmas in the academy, ed. T. Berry and N. Mizelle. Sterling, VA: Stylus Publishing.

Essien,V. (2003). Visible and invisible barriers to the incorporation of faculty of color in predominately white law schools. Journal of Black Studies, 34(1), 63-71.

Geronimus, A.T. (2006). "Weathering" and Age Patterns of Allostatic Load Scores Among Blacks and Whites in the United States. American Journal of Public Health, 96(5), 826-833.

Jacobs, L., Cintron, J., \& Canton, C. (2002). The politics of survival in academia: Narratives of inequity, resilience and success. Lanham, MD: Rowman \& Littlefield Publishers.

Joseph, T.D. \& Hirschfield, L.E. (2011). 'Why don't you get somebody new to do it?' Race and cultural taxation in the academy. Ethnic and racial studies, 34(1), 121-141.

McGee, E.O. (September 11, 2015). Inside Academia black professors are expected to entertain while presenting. The Conversation. (http://theconversation.com/inside-academia-black-professors-are-expected-to-entertainwhile-presenting-46249)/ ).

McGee, E.O. \& Kazembe, L. (August, 2015). Presenting While Black: African American Speakers Face Challenges at Conferences. The Journal of Blacks in Higher Education. (https://www.jbhe.com/2015/08/presenting-while-blackafrican-american-speakers-face-challenges-at-conferences/).

National Center for Education Statistics. (2014). Table 315.20. Full-time faculty in degree-granting postsecondary institutions, by race/ethnicity, sex, and academic rank: Fall 2009, fall 2011, and fall 2013. Digest of Education Statistics. http://nces.ed.gov/programs/coe/indicator_cuf.asp 
National Democratic Institute. (2015). Political inclusion of marginalized groups. Retrieved from https://www.ndi.org/political-inclusion-of-marginalized-groups

Padilla, A.M. (1994). Ethnic minority scholars, research, and mentoring: Current and future issues. Educational Researcher, 23(4), 24-27.

Ruffins, P. (1997). The fall of the house of tenure. Black Issues in Higher Education, 14(7), 19-26.

Segura, DA. (2003). Navigating between two worlds: The labyrinth of chicana intellectual production in the academy. Journal of Black Studies, 34(1), 28-51.

Smith, M.S. (2010). Gender, whiteness, and 'other Others' in the academy. In States of race: Critical race feminism for the $21^{\text {st }}$ century, ed. S. Razack, M. Smith and S. Thobani, 37-58. Toronto: Between the Lines.

Smith, W.A. (2016). Understanding the corollaries of offensive racial mechanism, gendered racism, and racial battle fatigue. Center for Critical Race Studies at UCLA Research Brief, 1-4.

Stanley, C.A. (2006). Coloring the academic landscape: Faculty of color breaking the silence in predominately white colleges and universities. American Educational Research Journal, 43(4), 701-736.

Thomas, V.G. \& Hollenshead, C. (2001). Resisting from the margins: The coping strategies of black women and other women of color faculty. Journal of Negro Education, 70(3), 166-175.

Turner, C.S. (2003). Incorporation and marginalization in the academy: From border toward center for faculty of color? Journal of Black Studies, 34(1), 112-125. 